Бојана Ч. Грујић

Градска библиотека у Новом Саду bojana.grujic3@gmail.com
Прегледни рад

UDK 007:027.54]:004(497.113)

616.98:578.834(100)"2020"

https://doi.org/10.18485/bibliotekar.2020.62.2.9

\title{
ПОСЛОВАЬЕ ГРАДСКЕ БИБЛИОТЕКЕ У НОВОМ САДУ У ВРЕМЕ ЕПИДЕМИЈЕ КОВИДА-19 - ИСТРАЖИВАњЕ ПУБЛИКЕ
}

Сажетак: Након избијања епидемије заразне болести ковид-19, узроковане корона вирусом, Градска библиотека у Новом Саду прилагодила је своје пословање епидемиолошкој ситуацији и донела План йримене мера зашиииие зайослених у Граяској библиотеии у Новом Саgу за време итрајана ванреgноі сииана. У току прве године спровођења Сӣрайеіије развоја Граgске библиоиекке у Новом Саgу (2020-2024) предвиђено је почетно истраживање публике, као и испуњење стратешких циљева увођења иновација и развоја публике. У складу са тим, у августу-септембру 2020. спроведено је анкетирање корисника ради увида у ставове према начину на који послује Библиотека и сазнања како побољшати корисничко искуство. Осим прихватања спроведених мера приликом позајмице и предлога за њено побољшање, у средишту истраживања био је однос према библиотечким онлајн услугама и корисничка предвиђања будућности библиотеке као установе. Упоређени су ставови корисника у градским одељењима и огранцима са гледиштима корисника приградских огранака и онима који су анкету попунили у електронском облику. Широки спектар онлајн услуга почео је да се развија и пре почетка пандемије, као што је стратешки и било предвиђено, а експанзија заразе додатно је убрзала рад на овом пољу.

Кључне речи: Градска библиотека у Новом Саду, епидемија, ковид-19, корона вирус, истраживање публике, корисничко искуство, анкета, услуге.

\section{Увод}

У оквиру Сйрайейије развоја Граяске библиоиеке у Новом Саgу (2020-2024), ${ }^{1}$ донете у септембру 2019. године, Библиотека је као један од

Градска библиотека у Новом Саду, Сӣрайейија развоја Граяске библиоиееке у Новом Cagy (2020-2024) (Нови Сад: А. Јокановић и Б. Грујић, 2019), https://www.gbns.rs/images/ dokumenti/STRATEGIJA_RAZVOJA_2020-2024.pdf (преузето 3. 10. 2020). 
стратешких циљева дефинисала Развој ӣублике, а у оквиру њега потциљ Истираживаюе йублике раgи gефинисана иррофила корисника и юихових очекиваюа, йойреба и навика. ${ }^{2}$ Према стратешком акционом плану, почетно истраживање публике треба да буде спроведено током 2020, најкасније до 31. децембра, а завршно до истека 2024. године. ${ }^{3}$

Потребу за оваквим истраживањем додатно је истакла нагла промена услова пословања, која је и зацртала начин истраживања. Наиме, пандемија ковида-19, заразне болести узроковане корона вирусом, која је Србију погодила 6. марта 2020, утицала је на свеукупни друштвени живот и изменила начин функционисања установа.

Након што је у недељу, 15. марта, у целој земљи уведено ванредно стање, у току наредне седмице у Библиотеци је обустављен рад са корисницима и прешло се на онлајн пословање. Информационо-реферални центар Библиотеке, који путем интернета послује од свог оснивања 2006. године, наставио је да ову врсту услуге пружа на даљину, док су остала одељења и огранци осмислили и реализовали читав спектар нових садржаја, доступних путем интернет мреже, како би задржали пажњу својих корисника и омогућили им да и даље користе услуге своје библиотеке. ${ }^{4}$ Крајем априла, донет је План ирримене мера зашишите зайослених у Граяској библиотеии у Новом Саgу за време йрајатьа ванреgноі стиана. ${ }^{5}$ У мају је ванредно стање обустављено и отпочео је поновни рад са корисницима, у измењеном режиму.

Пошто је ситуација у којој су се све библиотеке на свету нашле била сасвим нова, услед недостатка инструкција које су се тицале поступања са библиотечком грађом, на основу општих мера превенције донетих од стране градског кризног штаба, а касније и препорука библиотека у свету, које је пренео Богдан Трифуновић, председник Библиотекарског друштва Србије, ${ }^{6}$ Библиотека је донела неколико конкретних мера:

2 Градска библиотека у Новом Саду, Сӣрайейија развоја Граgске библиоиееке у Новом Саgу (2020-2024) (Нови Сад: А. Јокановић и Б. Грујић, 2019), стр. 54.

3 Исто, стр. 60

4 Више о овим активностима видети у: Весна Живковић, „Културни програми током пандемије ковида-19”, Библиотекар год. LXII, св. 2 (2020; рад прихваћен за штампање), и „Дигитално читање”, Мозаик - информативно гласило Градске библиотеке у Новом Саду год. XXII, бр. 133 (2020), у припреми.

5 Градска библиотека у Новом Саду, План ирримене меразашиичииезайослениху Граgској библиотеиеци у Новом Саgу за време тирајань в ванреgної сйаюа (Нови Сад: С. Миљуш, 2020), https:// www.facebook.com/GradskaBibliotekaNoviSad/photos/a.367124053302423/3623961180952011 (преузето 24. 4. 2020).

6 Богдан Трифуновић, Преgлої ирееиорука и мера раgа библиоиека йоком тирајаюа ванреgноі стйана изазваної covid-19 йанgемијом, имејл порука на групи [BDS lista], 24. април 2020. 
1. књиге се могу изнајмљивати свакодневно, и то по две;

2. током маја враћање књига вршило се само петком, како би се дезинфиковале, након чега су враћане у фонд. Већ од јуна, враћање књига није више било ограничено на један дан седмично него их је било могуће вратити сваког дана;

3. привремено је обустављено примање поклон-књига;

4. корисницима се услуга пружа са импровизованих пултова на улазу, са инструкцијама где се одлажу враћене, а на којој страни стоје новоизнајмљене књиге. Руковање грађом и за запослене и за кориснике обавезно се врши у рукавицама, са заштитном маском или визиром на лицу, уз поштовање прописане физичке дистанце. На свим улазима налазе се дезобаријере, а у простору се свакодневно врши дезинфекција. Сваког јутра дезинфикују се враћене књиге. У централној згради Библиотеке отворена су и два додатна пункта из Дунавске улице, једно на Дечјем, а друго на Одељењу „Ђура Даничић”;

5. обустављени су сви програми који подразумевају присуство публике, осим на отвореном, односно у простору који својом површином дозвољава минимални број учесника, као што је то новоотворени Диіитиални омлаgински иенйар, а интензивирали су се онлајн програми и садржаји доступни путем интернета;

6. Научна и Читаоница штампе биле су отворене за кориснике краћи период, да би, након погоршања епидемиолошке ситуације у јуну, биле привремено затворене, а отворена Библиотека на Штранду - дунавској плажи - која је, захваљујући лепом времену, осим јула и августа, радила и цео септембар.

Интересовало нас је како су наши корисници примили прописане мере и како оцењују рад Библиотеке у условима епидемије. Стога смо спровели истраживање публике, чији је циљ био трострук: са једне стране, желели смо да проверимо у којој мери су се корисници наших фондова адаптирали на мере које смо спровели, односно имају ли предлоге, критике и усмерења за побољшања; са друге стране, било нам је значајно да утврдимо колико смо успели да електронским садржајима надоместимо библиотечке услуге у физичком облику и каква побољшање се очекују на том пољу, а са треће, интересовала су нас корисничка предвиђања: хоће ли епидемија умногоме променити библиотечко пословање и како они Библиотеку виде у будућности.

Пошли смо од претпоставке да су корисници у већем броју задовољни начином на који Библиотека ради, да су им интернет садржаји и услуге доступни и занимљиви, а да у будућности не виде значајне промене у библиотечком пословању. 
Користили смо дескриптивни метод и технику анкетирања, користећи инструмент у форми кратког анонимног упитника, сачињеног од два питања затвореног и три питања отвореног типа (Слика 1). Прва два питања тицала су се физичке позајмице у фонду, друга два односила су се на онлајн садржаје, а последње питање тражило је пројектовање будућности Библиотеке. Време утрошено за попуњавање анкете процењено је на пет минута.

AHKETA

Од марта 2020. године наша земља суочава се с пандемијом корона вируса, те је наша библиотека, као и друге установе, била принуђена да уобичајени начин пословања прилагоди новонасталој ситуацији. Изузетно нам је значајно Ваше мишљење о томе колико успевамо да, у складу са прописаним мерама заштите, и даље излазимо у сусрет Вашим жељама и потребама, те Вас молимо да, у циљу унапређења наших услуга, испуните овај кратки упитник:

1. Какве су мере превентивне заштите које се спроводе у централној згради Библиотеке и њеним огранцима? (заокружите одговор)
- Веома добре
- Добре
- Задовољавајуће
○ Лоше

2. Шта је потребно унапредити и на који начин побољшати услуге приликом личног контакта (позајмице књига)?

3. Да ли посећујете електронске презентације Библиотеке на интернету (електронски каталог, сајт, Фејсбук, Инстаграм, YouTube, Cityguide? (заокружите одговор)
○ Често
○ Понекад
○ Ретко
○ Никад

4. Уколико посећујете наше електронске презентације, на који начин сматрате да би електронске услуге које нудимо требало да се побољшају и учине занимљивијима?

5. Да ли сматрате да һе се пандемија дугорочно одразити на пословање Библиотеке и какав правац у деловању према заједници, по вашем мишљењу, треба одабрати?

Хвала на времену које сте издвојили у сврху унапређења наших услуга.

ваша библиотека

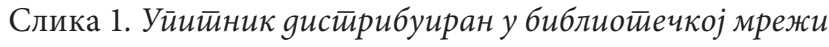


Приликом истраживања коришћен је случајни узорак циљне популације, која се састоји из двеју циљних група: једна група су особе које физички долазе у библиотеку (корисници фондова и конзументи програма), а друга група су онлајн корисници. Осим разлика у оквиру ове две групе, такође ћемо утврдити има ли разлике у одговорима корисника у градским и приградским огранцима. Како смо ранијим истраживањима утврдили да су разлике између начина пословања огранака у граду и огранака у приградским насељима незнатне, и у оквиру овог истраживања очекивали смо сличне резултате.

Период прикупљања података започео је 6. августа, а закључен је 18. септембра 2020. године. ${ }^{7}$

\section{Ток истраживања}

Анкета је у папирној форми пуштена у 12 градских одељења и огранака, од којих је на њу одговорено у 10 („Ђура Даничић”, Дечје одељење, „Стеван Сремац”, „Шандор Петефи”, „Данило Киш”, „Владимир Назор”, „Коста Трифковић”, „Жарко Зрењанин”, „Аница Савић Ребац” и Дигитални омладински центар) и у Библиотеци на Штранду, те је укупна покривеност истраживањем у градским огранцима 91,67\%. Корисници Дечјег одељења и Огранка „Стеван Сремац” одговарали су на њу претежно у електронској форми, јер је немогућност уласка у библиотеку и непостојање заштите од сунца испред библиотеке утицала на то да максимално редукују време ту проведено и ограниче га искључиво на враћање прочитаних и узимање нових књига. Објашњење да су анкету радије попунили у електронској форми дали су и корисници Завичајне збирке. ${ }^{8}$

7 Истраживањем је координисала и анализу резултата извршила виши дипломирани библиотекар МА Бојана Грујић, руководилац Одељења за унапређење, надзор и развој библиотечке делатности, уз подршку помоћника директора дипломираног библиотекара Александра Јокановића, чланова Одељења: дипломираног библиотекара МА Весне Живковић и Генадија Мојсина, информатичара, као и дипломираног библиотекара-информатичара Неде Бабић, администратора сајта и Фејсбук странице Библиотеке. Директно учешће у истраживању имали су запослени у библиотечким одељењима и огранцима, који су своје кориснике мотивисали да се укључе у истраживање.

8 Градски огранци и одељења у које анкета није пуштена јесу „Вељко Петровић” (огранак није радио у јулу и августу), Информационо-реферални центар са Читаоницом и Читаоница штампе (били су затворени за физичко присуство корисника; први је пружао само онлајн услуге и само краћи период након укидања ванредног стања услуживао мањи број корисника). 
Анкету је добило 14 приградских огранака, а одговори су стигли из њих 11 (или 78,57\%): „Бранко Радичевић” у Сремским Карловцима, „Јован Јовановић Змај” у Сремској Каменици, „Ђорђе Арацкић” у Лединцима, „Јован Јовановић Змај” у Футогу, „Михал Бабинка” у Кисачу, „Лаза Костић” у Ковиљу, „Ђура Јакшић” у Каћу, „Ендре Ади” у Будисави, „Милица Стојадиновић Српкиња” у Буковцу, „Тоша Трифунов” у Бегечу и „Петар Кочић” у Ветернику.

У укупно 26 одељења и огранака анкета је дистрибуирана у физичкој форми (за свако одељење и огранак додељено је по 20 листова анкете; укупно 520, са могућношћу да сваки библиотекар одштампа још онолико колико му буде требало). У Табели 1 дат је преглед броја попуњених анкетних листића по одељењима и огранцима.

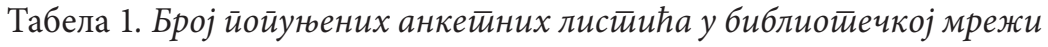

\begin{tabular}{|c|c|c|c|c|c|}
\hline $\begin{array}{l}\text { P. } \\
\text { бр. }\end{array}$ & $\begin{array}{c}\text { ГРАДСКА ОДЕЉЕЊА } \\
\text { И ОГРАНЦИ }\end{array}$ & $\begin{array}{l}\text { Број } \\
\text { одгов. }\end{array}$ & $\begin{array}{l}\text { P. } \\
\text { бр. }\end{array}$ & $\begin{array}{c}\text { ПРИГРАДСКИ } \\
\text { ОГРАНЦИ }\end{array}$ & $\begin{array}{l}\text { Број } \\
\text { одгов. }\end{array}$ \\
\hline 1. & $\begin{array}{c}\text { Ђура Даничић } \\
\text { Дунавска } 1\end{array}$ & 16 & 12. & $\begin{array}{l}\text { Бранко Радичевић, } \\
\text { Сремски Карловци }\end{array}$ & 27 \\
\hline 2. & $\begin{array}{l}\text { Дечје одељење } \\
\text { Дунавска } 1\end{array}$ & 2 & 13. & $\begin{array}{l}\text { Јован Јовановић Змај, } \\
\text { Сремска Каменица }\end{array}$ & 12 \\
\hline 3. & $\begin{array}{c}\text { Стеван Сремац } \\
\text { Народних хероја } 5\end{array}$ & 1 & 14. & $\begin{array}{c}\text { Ђорђе Арацкић, } \\
\text { Лединци }\end{array}$ & 8 \\
\hline 4. & Шандор Петефи, Телеп & 20 & 15. & $\begin{array}{c}\text { Јован Јовановић Змај, } \\
\text { Футог }\end{array}$ & 20 \\
\hline 5. & Данило Киш, Лиман & 13 & 16. & Михал Бабинка, Кисач & 20 \\
\hline 6. & $\begin{array}{l}\text { Владимир Назор } \\
\text { Петроварадин }\end{array}$ & 6 & 17. & Лаза Костић, Ковиљ & 10 \\
\hline 7. & $\begin{array}{c}\text { Коста Трифковић } \\
\text { Детелинара }\end{array}$ & 18 & 18. & Ђура Јакшић, Каћ & 6 \\
\hline 8. & $\begin{array}{c}\text { Жарко Зрењанин } \\
\text { Ново насеље }\end{array}$ & 21 & 19. & $\begin{array}{c}\text { Ендре Ади, } \\
\text { Будисава }\end{array}$ & 11 \\
\hline 9. & $\begin{array}{c}\text { Аница Савић Ребац } \\
\text { Трг Републике } 2\end{array}$ & 6 & 20. & $\begin{array}{c}\text { Милица Стојадиновић } \\
\text { Српкиња, Буковац }\end{array}$ & 10 \\
\hline 10. & $\begin{array}{c}\text { Диг. омладински центар } \\
\text { Војводе Путника } 1\end{array}$ & 7 & 21. & Тоша Трифунов, Бегеч & 20 \\
\hline \multirow[t]{2}{*}{11.} & Библиотека на Штранду & 10 & 22. & Петар Кочић, Ветерник & 20 \\
\hline & Укупно & 120 & & Укупно & 164 \\
\hline
\end{tabular}

9 Приградски огранци који нису учествовали у истраживању су: „Никола Тесла” у Степановићеву, „Иво Андрић” у Руменки и „Трифун Димић” у Шангају. 
Од предвиђеног броја одељења и огранака (26), у истраживању је учествовало њих 22 (84,62\%), а од 520 празних анкетних листића, одговорено је на 284 (54,62\%).

При посматрању дистрибуције бројева у Табели 1, треба имати на уму околности и факторе који су утицали на овакве резултате:

1. однос корисника према библиотеци у датим околностима: пандемија је променила начин пословања многих друштвених актера и приватних фирми, па је коришћење њихових услуга грађанима постало отежано у односу на услове који су постојали до марта 2020. Заједно са индивидуалним психолошким фактором подношења новог стања, чији се крај не назире, они засигурно утичу и на промену у стрпљењу и приоритетима чак и код вишегодишњих корисника библиотечких услуга, посебно старијих суграђана;

2. мотивисаност корисника: учешће у анкетирању понуђено је корисницима на основу добре воље. С обзиром на чињеницу да су у задатом периоду били лоцирани испред библиотеке, на сунцу, чекајући на свој ред и трудећи се да максимално смање време задржавања, додатно време потребно за попуњавање листића било је, на неки начин, „одузето” и њима и корисницима који чекају после њих, па је потпуно разумљиво што се одређени број корисника, који би анкету у другачијим условима радо попунили, радије опредељивао да то не учини, или да је попуни путем интернета, у комфорнијим условима;

3. однос корисника и библиотекара: библиотекари који имају професионално близак и отворен однос са својим корисницима успешније су прибавили задати број попуњених анкетних листића. Треба имати у виду да је овакав однос лакше успоставити у огранцима који су мање фреквентни;

4. мотивисаност библиотекара: мотивација библиотекара да изађе из своје зоне комфора и замоли кориснике да дају своје мишљење такође је утицала на број попуњених листића. Анкетирање остварује двоструку корист: библиотека добија смернице за побољшање свога рада, а корисници су на још један начин укључени у њен рад, стичући могућност да креирају услуге по својој мери. Библиотекари који су анкети приступили са свешћу о томе успешније су остварили свој задатак.

У електронској верзији истоветна анкета креирана је у апликацији Google Forms, за коју је линк (https://docs.google.com/forms/d/1o3wIkkULT 4N1FokG_yE8bv7rUGP4KVBBDJNcULpfTbY/) постављен на Фејсбук страници Библиотеке, која има 7.359 сталних пратилаца. Овај линк подељен је и имејлом двема групама корисника Библиотеке: једну групу чини публика 
која посећује културне програме, на чије адресе електронске поште Библиотека шаље позивнице (мејлинг листа), а којих је укупно 400. Друга група су корисници чије имејл адресе Библиотека похрањује у свом информационом систему Бисис, од чијих је адреса у периоду посматрања формирана Google група, која броји укупно 1.556 чланова. Електронска анкета нашла се и на званичној интернет страници Библиотеке www.gbns.rs, на којој је у посматраном периоду кликнуйо 3.989 пута. Од укупног броја корисника који имају приступ електронским информацијама Библиотеке, чији се број процењује на 8.059, на анкету их је одговорило укупно 80 (10 на сајту, 70 на платформи Google Forms), што чини свега 0,99\%. Претпоставка је да се групе учесника у истраживању преклапају, те да они који су на анкету одговорили у писаној форми, приликом позајмице књига, нису одговарали на анкету у електронском облику, као и да је одређени број чланова Google групе истовремено и члан мејлинг листе посетилаца културних програма.

\section{Циљне групе}

Анкета је конципирана тако да су у истраживању маркиране две основне циљне групе: корисници који посећују библиотеку ради позајмице библиотечко-информационе грађе и корисници електронских услуга.

1. Корисници библиотечких фондова посетиоци Библиотеке који су анкету попунили у писаној форми $284(78,02 \%)$

2. Корисници библиотечких електронских услуга који су анкету попунили у онлајн облику ..... $80(21,98 \%)$ Укупно: $364(100,00 \%)$

За потребе поређења, прву групу смо поделили на две подгрупе: на кориснике фондова у граду и оне који читају у приградским насељима. Кориснике електронских услуга поделили смо на оне који користе сајт и оне који су до анкете дошли путем директног линка.

Истраживањем су, дакле, обухваћене ове четири подгрупе:

1. Корисници фондова градских одељења и огранака .. $120(32,97 \%)$

2. Корисници фондова приградских огранака ............... 164 (45,05\%)

3. Посетиоци сајта Библиотеке .......................................... 10 (2,75\%) 
4. Чланови Google групе (корисници чије се адресе електронске поште налазе у Бисису), посетиоци Фејсбук странице Библиотеке, публика на књижевним вечерима којој се позивнице шаљу електронски - путем линка на Google Forms-y Укупно: $364(100,00 \%)$

Узевши у обзир све речено, определили смо се да у анализи посматрамо три групе корисника, односно публике. Услед уочавања сличности и разлика у пословању градских и приградских огранака, који раде у донекле различитим срединама, анализираћемо анкету тако што ћемо их посматрати одвојено. Посебно ћемо анализирати и одговоре корисника који су попунили електронску анкету, па ће преглед наших учесника у истраживању изгледати овако:

1. Корисници фондова градских одељења и огранака ...

2. Корисници фондова приградских огранака $120(32,97 \%)$

3. Корисници библиотечких електронских услуга који су анкету попунили у онлајн облику $164(45,05 \%)$ Укупно: $364(100,00 \%)$

Прикупљена су укупно 364 попуњена упитника. Највећи број одговора дали су корисници фондова у приградским огранцима, укупно 164, што чини 45,05\% од укупног броја одговора. Следе корисници фондова градских одељења и огранака са 32,97\% и закључујемо да је већина одговора на анкету стигла из библиотечке мреже, од корисника који су физички посетили библиотеку, њих укупно 78,02\%. На електронски вид упитника одговорило је $21,98 \%$ анкетираних. ${ }^{10}$

\section{Анализа}

У уводном објашњењу, на анкетном листићу стајало је: $O g$ марй $а$ 2020. іолине наша земль суочава се с йандемијом корона вируса, йе је наша

10 Верзија за штампу, која је пред вама, није укључила три поглавља која садрже засебне анализе резултата анкетирања у градским одељењима и огранцима, приградским огранцима и у оквиру електронске анкете. Резултати истраживања употпуњени овим детаљима моћи ће се погледати на сајту Библиотеке (www.gbns.rs) након објављивања овог текста. 
библиоиекка, као и gруіе устианове, била ирринуђена gа уобичајени начин ӣо-

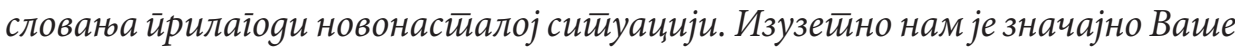
мишъьене о ииоме колико усиевамо gа, у склаgу са ирройсаним мерама заш-

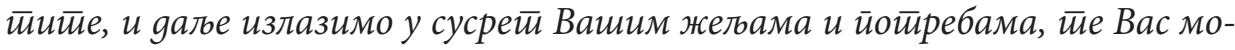
лимо gа, у иилу унайређень наших услуїа, исиууниие овај крайки уйийник.

Прво питање је било: Какве су мере йревениииве заштиите које се

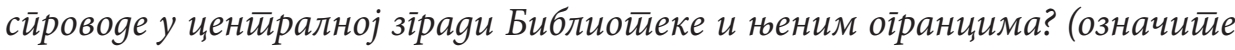
ogīoвор). Понуђени одговори били су: веома добре, добре, задовољавајуће, лоше. Одговори су били следећи:

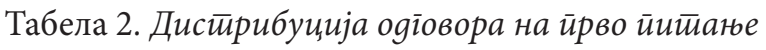

\begin{tabular}{|c|c|c|c|c|c|c|}
\hline $\begin{array}{l}\text { P. } \\
\text { б. }\end{array}$ & Циљна група & $\begin{array}{l}\text { Веома } \\
\text { добре }\end{array}$ & Добре & $\begin{array}{c}\text { Задовоља- } \\
\text { вајуће }\end{array}$ & Лоше & Укупно \\
\hline 1. & $\begin{array}{l}\text { Градска одеље- } \\
\text { ња и огранци }\end{array}$ & $\begin{array}{c}\mathbf{8 2} \\
(22,53 \%)\end{array}$ & $\begin{array}{c}31 \\
(8,52 \%)\end{array}$ & $\begin{array}{c}\mathbf{6} \\
(1,65 \%)\end{array}$ & $\begin{array}{c}\mathbf{1} \\
(0,27 \%)\end{array}$ & $\begin{array}{c}120 \\
(32,97 \%)\end{array}$ \\
\hline 2. & $\begin{array}{l}\text { Приградски } \\
\text { огранци }\end{array}$ & $\begin{array}{c}106 \\
(29,12 \%)\end{array}$ & $\begin{array}{c}33 \\
(9,06 \%)\end{array}$ & $\begin{array}{c}24 \\
(6,59 \%)\end{array}$ & $\begin{array}{c}\mathbf{1} \\
(0,27 \%)\end{array}$ & $\begin{array}{c}164 \\
(45,05 \%)\end{array}$ \\
\hline 3. & $\begin{array}{l}\text { Електронска } \\
\text { анкета }\end{array}$ & $\begin{array}{c}\mathbf{5 4} \\
(14,83 \%)\end{array}$ & $\begin{array}{c}\mathbf{1 8} \\
(4,95 \%)\end{array}$ & $\begin{array}{c}\mathbf{8} \\
(2,20 \%)\end{array}$ & $\begin{array}{c}\mathbf{0} \\
(0,00 \%)\end{array}$ & $\begin{array}{c}\mathbf{8 0} \\
(21,98 \%)\end{array}$ \\
\hline & Укупно & $\begin{array}{c}242 \\
(66,48 \%)\end{array}$ & $\begin{array}{c}82 \\
(22,53 \%)\end{array}$ & $\begin{array}{c}38 \\
(10,44 \%)\end{array}$ & $\begin{array}{c}2 \\
(0,55 \%)\end{array}$ & $\begin{array}{c}364 \\
(100,00 \%)\end{array}$ \\
\hline
\end{tabular}

Из резултата је очигледно да већина корисника мреже огранака и одељења Градске библиотеке у Новом Саду - њих 66,48\% - сматра да су мере веома добре. Заједно са оних 22,53\%, који сматрају да су мере добре, можемо закључити да је $89,01 \%$ корисника задовољно начином на који им је пружена библиотечка услуга при позајмици грађе. Проценат од непуних 11\% има замерке, које су изнели у наредном питању. Проценат оних који мере сматрају веома добрима $(29,12 \%)$ и добрима $(9,06 \%)$ највећи је у приградским огранцима, а за њима следе корисници градских одељења и огранака, са $22,53 \%$, односно $8,52 \%$. Физичком услугом најмање су задовољни корисници који су упитник попуњавали електронски. Да су мере веома добре сматра их 14,83\%, да су добре 4,95\%, што чини 19,78\% учесника у анкетирању.

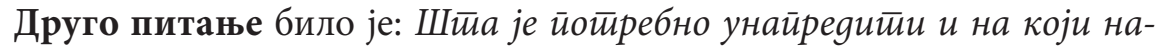

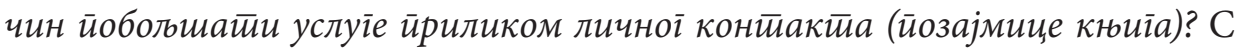
обзиром на то да је питање било отвореног типа, тражили су се писани одговори, које је било могуће груписати на следећи начин: 


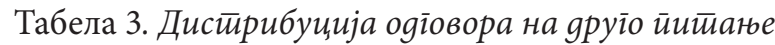

\begin{tabular}{|c|c|c|c|c|c|c|c|c|}
\hline $\begin{array}{l}\text { P. } \\
\text { б. }\end{array}$ & $\begin{array}{l}\text { Циљна } \\
\text { група }\end{array}$ & 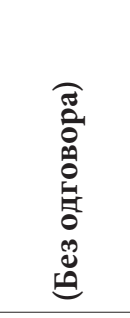 & 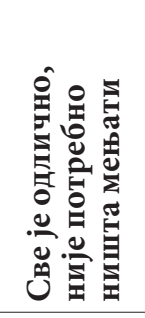 & 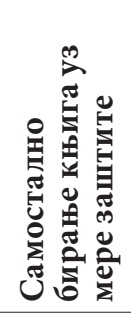 & 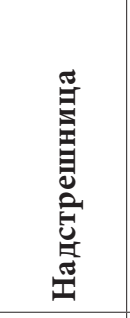 & 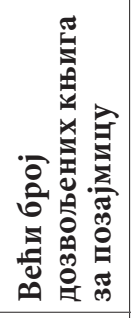 & 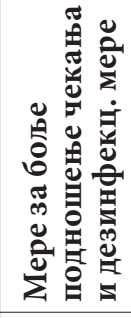 & 莣 \\
\hline 1. & $\begin{array}{l}\text { Градска } \\
\text { одељења } \\
\text { и огранци }\end{array}$ & $\begin{array}{c}35 \\
(9,62 \%)\end{array}$ & $\begin{array}{c}36 \\
(9,89 \%)\end{array}$ & $\begin{array}{c}12 \\
(3,30 \%)\end{array}$ & $\begin{array}{c}15 \\
(4,12 \%)\end{array}$ & $\begin{array}{c}11 \\
(3,03 \%)\end{array}$ & $\begin{array}{c}11 \\
(3,02 \%)\end{array}$ & $\begin{array}{c}\mathbf{0} \\
(0,00 \%)\end{array}$ \\
\hline 2. & $\begin{array}{l}\text { Приградски } \\
\text { огранци }\end{array}$ & $\begin{array}{c}24 \\
(6,59 \%)\end{array}$ & $\begin{array}{c}\mathbf{6 2} \\
(17,03 \%)\end{array}$ & $\begin{array}{c}\mathbf{1 6} \\
(4,40 \%)\end{array}$ & $\begin{array}{c}\mathbf{0} \\
(0,00 \%)\end{array}$ & $\begin{array}{c}\mathbf{3} \\
(0,82 \%)\end{array}$ & $\begin{array}{c}35 \\
(9,62 \%)\end{array}$ & $\begin{array}{c}\mathbf{2 4} \\
(6,59 \%)\end{array}$ \\
\hline 3. & $\begin{array}{l}\text { Електронска } \\
\text { анкета }\end{array}$ & $\begin{array}{c}\mathbf{3} \\
(0,82 \%)\end{array}$ & $\begin{array}{c}\mathbf{5 3} \\
(14,56 \%)\end{array}$ & $\begin{array}{c}\mathbf{5} \\
(1,37 \%)\end{array}$ & $\begin{array}{c}\mathbf{2} \\
(0,55 \%)\end{array}$ & $\begin{array}{c}\mathbf{0} \\
(0,00 \%)\end{array}$ & $\begin{array}{c}17 \\
(4,67 \%)\end{array}$ & $\begin{array}{c}\mathbf{0} \\
(0,00 \%)\end{array}$ \\
\hline & Укупно & $\begin{array}{c}62 \\
(17,03 \%)\end{array}$ & $\begin{array}{c}151 \\
(41,48 \%)\end{array}$ & $\begin{array}{c}33 \\
(9,07 \%)\end{array}$ & $\begin{array}{c}17 \\
(4,67 \%)\end{array}$ & $\begin{array}{c}14 \\
(3,85 \%)\end{array}$ & $\begin{array}{c}63 \\
(17,31 \%)\end{array}$ & $\begin{array}{c}24 \\
(6,59 \%)\end{array}$ \\
\hline
\end{tabular}

Питање је постављено тако да се може закључити како анкетирани корисници који на ово питање нису одговорили, њих 62 (17,03\%) сматрају да није потребно ништа унапредити, то јест да је пословање које се тиче позајмице организовано на очекиван и прихватљив начин. Заједно са 151 корисником (41,48\%) који се изјаснио да не би ништа мењао, овај број износи 213, што је укупно 58,51\% укупног броја анкетираних корисника. Ови подаци говоре да је више од половине задовољно постојећом услугом. Они који би желели промене могу се сврстати у две групе: корисници који желе побољшање мера за подношење чекања и корисници који желе да уђу у библиотеку и самостално бирају књиге.

Корисника који желе побољшање мера за боље подношење чекања има 94 (25,82\%). Од овог броја, седамнаесторо (4,67\%) сматрају да је потребно поставити надстрешницу као заштиту од сунца и кише; четрнаесторо (3,85\%) предлажу различите начине на које би се чекање на књигу дало скратити. Један од њих је увођење електронске резервације, како би се књиге унапред наручиле. Предложено је да се пружи бољи преглед избора књига за читање, и то у смислу листе која би се послала корисницима имејлом, или избора датог на сајту. Корисници су уочили да је децу која чекају са родитељима потребно нечим забавити и предлажу ситне пажње. 
Тражено је више дезинфекције, постављање бесконтактног дезинфекционог средства, као и увођење бесконтактног враћања књига и постављање заштитног плексигласа. Предложено је и повећање броја књига које смеју да се изнајме, што би такође смањило фреквенцију корисника, то јест проредило њихове посете библиотеци, и тиме, посредно, смањило могућност преношења заразе. Потребно је рећи да је Библиотека иницирала набавку плексигласа за сва одељења и огранке, који ће у најскоријем року бити постављени на услужне пултове.

Корисници који желе да уђу у библиотеку и самостално бирају књиге предлажу да се то чини уз поштовање дозвољеног броја особа које могу боравити у затвореном простору, уз прописану дистанцу и употребу заштитних средстава. Њих је укупно 33, што чини $\mathbf{9 , 0 7 \%}$ укупног броја анкетираних. Овај податак нам потврђује да наши корисници - људи који имају навику и потребу за читањем - заиста сматрају своју библиотеку нечим већим од пуког магацина књига и да је боравак у библиотеци важан део њиховог духовног живота.

Остатак од наведеног, двадесет четворо корисника (6,59\%), сви из приградских огранака, траже специфичности у виду двосменског рада (огранак у Сремским Карловцима) и едукације (Буковац), што није у директној вези са пословањем у време пандемије, али јесте важна информација за свеукупно пословање Библиотеке.

Треће питање: Да ли йосећујетие елекииронске йрезенитаиије Библи-

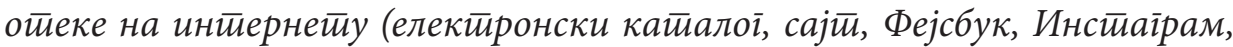
YouTube, Cityguide? (означuйе ogīoвор) било је затвореног типа и тражило је да се одговори на један од четири начина: често, понекад, ретко и никад:

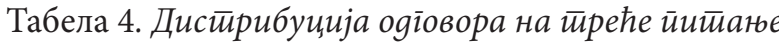

\begin{tabular}{|c|l|c|c|c|c|c|}
\hline $\begin{array}{c}\text { Р. } \\
\text { б. }\end{array}$ & Циљна група & Често & Понекад & Ретко & Никад & Укупно \\
\hline 1. & $\begin{array}{l}\text { Градска одеље- } \\
\text { Һа и огранци }\end{array}$ & $\begin{array}{c}\mathbf{1 2} \\
(3,30 \%)\end{array}$ & $\mathbf{4 0}(10,99 \%)$ & $\begin{array}{c}\mathbf{3 1} \\
(8,52 \%)\end{array}$ & $\begin{array}{c}\mathbf{3 7} \\
(10,16 \%)\end{array}$ & $\begin{array}{c}\mathbf{1 2 0} \\
(32,97 \%)\end{array}$ \\
\hline 2. & $\begin{array}{l}\text { Приградски } \\
\text { огранци }\end{array}$ & $\begin{array}{c}\mathbf{1 9} \\
(5,22 \%)\end{array}$ & $\begin{array}{c}\mathbf{5 1} \\
(14,01 \%)\end{array}$ & $\begin{array}{c}\mathbf{5 2} \\
(14,29 \%)\end{array}$ & $\begin{array}{c}\mathbf{4 2} \\
(11,54 \%)\end{array}$ & $\begin{array}{c}\mathbf{1 6 4} \\
(45,05 \%)\end{array}$ \\
\hline 3. & $\begin{array}{l}\text { Електронска } \\
\text { анкета }\end{array}$ & $\begin{array}{c}\mathbf{1 8} \\
(4,94 \%)\end{array}$ & $\begin{array}{c}\mathbf{2 9} \\
(7,97 \%)\end{array}$ & $\begin{array}{c}\mathbf{1 9} \\
(5,21 \%)\end{array}$ & $\begin{array}{c}\mathbf{1 4} \\
(3,85 \%)\end{array}$ & $\begin{array}{c}\mathbf{8 0} \\
(21,98 \%)\end{array}$ \\
\hline & $\begin{array}{c}\mathbf{4 9} \\
\mathbf{( 1 3 , 4 6 \% )}\end{array}$ & $\begin{array}{c}\mathbf{1 2 0} \\
\mathbf{( 3 2 , 9 7 \% )}\end{array}$ & $\begin{array}{c}\mathbf{1 0 2} \\
\mathbf{( 2 8 , 0 2 \% )}\end{array}$ & $\begin{array}{c}\mathbf{9 3} \\
\mathbf{( 2 5 , 5 5 \% )}\end{array}$ & $\begin{array}{c}\mathbf{3 6 4} \\
(\mathbf{1 0 0 , 0 0 \% )}\end{array}$ \\
\hline
\end{tabular}


Из одговора на ово питање очигледно је да највише корисника електронске презентације Библиотеке посећује понекад (32,97\%) или ретко $(\mathbf{2 8 , 0 2 \% ) , ~ ш т о , ~ з а ј е д н о ~ с а ~ о н и х ~} \mathbf{1 3 , 4 6 \%}$ који их посећују често, чини $\mathbf{7 4 , 4 5 \%}$ од укупног броја анкетираних. Овај број нам говори да велики број суграђана зна за Библиотеку на интернету и где да пронађе информације, али исто тако нам каже да је број оних који редовно користе ову интернет услугу сразмерно мали. Треба пронаћи начин да се онлајн услуга учини видљивијом и приступачнијом.

Очекујемо да ће се број корисника који користе онлајн услуге Библиотеке у наредном периоду повећавати, с обзиром на следеће чињенице: постојећи асортиман услуга које су корисници могли да користе путем YouTube канала, Фејсбук странице и сајта Библиотеке обогаћен је новим садржајима који су почели да се развијају убрзано у марту 2020, након увођења ванредног стања и престанка рада са корисницима, који нису престали да се развијају и богате ни данас. У јулу је отворена страница на Инстаграму, а у септембру оформљена корисничка Google група, чиме су се информисаност и интеракција са корисницима додатно побољшале. Ова група биће одлична основа за спровођење следећег планираног корака: креирања мобилне апликације.

Нова услуга коју Библиотека однедавно нуди јесте Опак (Орас), онлајн каталог за персонализовану употребу корисника, а у завршној фази је и нови сајт Библиотеке, израђен по најсавременијим стандардима. Дигитални омладински центар, који је отворен у јуну 2020, производи онлајн садржаје занимљиве првенствено младима, али и свим другим старосним категоријама, преносећи уживо и снимајући концерте, промоције књига, разговоре, фестивале, радионице и друго. Осим тога, радиће се и на увођењу позајмице електронске књиге, где је први корак постављање сопствених издања у пуном тексту у онлајн каталог.

Четврто питање било је: Уколико йосећујетие наше елекиронске ӣре-

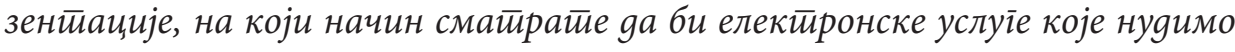
йребало gа се йобољиају и учине занимљивијима? Као питање отвореног типа добило је више одговора, који могу да се групишу на следећи начин: 


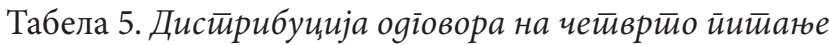

\begin{tabular}{|c|c|c|c|c|c|c|c|}
\hline $\begin{array}{l}\text { P. } \\
\text { б. }\end{array}$ & $\begin{array}{l}\text { Циљна } \\
\text { група }\end{array}$ & 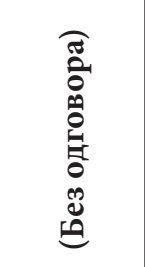 & 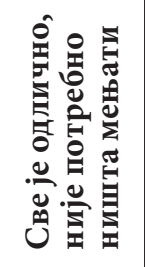 & 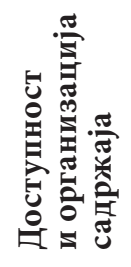 & 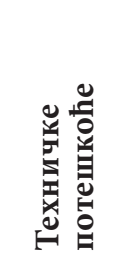 & 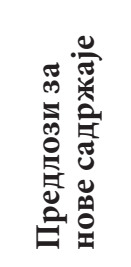 & 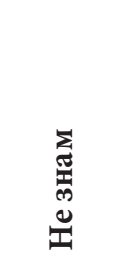 \\
\hline 1. & $\begin{array}{l}\text { Градска одељења } \\
\text { и огранци }\end{array}$ & $\begin{array}{c}\mathbf{8 4} \\
(23,08 \%)\end{array}$ & $\begin{array}{c}\mathbf{9} \\
(2,47 \%)\end{array}$ & $\begin{array}{c}\mathbf{8} \\
(2,20 \%)\end{array}$ & $\begin{array}{c}\mathbf{1 2} \\
(3,30 \%)\end{array}$ & $\begin{array}{c}\mathbf{5} \\
(1,37 \%)\end{array}$ & $\begin{array}{c}\mathbf{2} \\
(0,55 \%)\end{array}$ \\
\hline 2. & $\begin{array}{l}\text { Приградски } \\
\text { огранци }\end{array}$ & $\begin{array}{c}87 \\
(23,90 \%)\end{array}$ & $\begin{array}{c}35 \\
(9,62 \%)\end{array}$ & $\begin{array}{c}19 \\
(5,22 \%)\end{array}$ & $\begin{array}{c}10 \\
(2,75 \%)\end{array}$ & $\begin{array}{c}\mathbf{4} \\
(1,10 \%)\end{array}$ & $\begin{array}{c}9 \\
(2,47 \%)\end{array}$ \\
\hline 3. & $\begin{array}{l}\text { Електронска } \\
\text { анкета }\end{array}$ & $\begin{array}{c}15 \\
(4,12 \%)\end{array}$ & $\begin{array}{c}36 \\
(9,89 \%)\end{array}$ & $\begin{array}{c}\mathbf{5} \\
(1,37 \%)\end{array}$ & $\begin{array}{c}11 \\
(3,02 \%)\end{array}$ & $\begin{array}{c}13 \\
(3,57 \%)\end{array}$ & $\begin{array}{c}\mathbf{0} \\
(0,00 \%)\end{array}$ \\
\hline & Укупно & $\begin{array}{c}186 \\
(51,10 \%)\end{array}$ & $\begin{array}{c}80 \\
(21,98 \%)\end{array}$ & $\begin{array}{c}32 \\
(8,79 \%)\end{array}$ & $\begin{array}{c}33 \\
(9,07 \%)\end{array}$ & $\begin{array}{c}22 \\
(6,04 \%)\end{array}$ & $\begin{array}{c}11 \\
(3,02)\end{array}$ \\
\hline
\end{tabular}

На ово питање није одговорило 186 корисника (51,10\%), а од тог броја деведесет троје (тачно половина) их је оних који су у претходном питању одговорили да никад не посећују интернет презентације Библиотеке. За осталих деведесет троје можемо закључити да немају примедби на њене интернет садржаје. Заједно са још 80 корисника који су написали да су задовољни (21,98\%), број оних који не би ништа мењали износи 173 , што представља 47,53\% броја анкетираних који посећују интернет презентације Библиотеке. Остали учесници истраживања дали су своја запажања, која можемо поделити на: напомене у вези са доступношћу и организацијом садржаја, напомене у вези са техничким потешкоћама и конкретне предлоге за нове садржаје.

Напомене у вези са доступношћу и организацијом садржаја:

Напомене у овом сегменту дала су укупно 32 (8,79\%) учесника анкете.

Од овог броја, потребу за повећањем видљивости и домета онлајн услуга плаћањем додатних сервиса на интернету истиче осморо $(2,2 \%)$ анкетираних. На овом плану се управо у току трајања истраживања урадило то да су Библиотека и сви њени огранци појединачно добили своју презентацију на интернет водичу кроз градове и дешавања Cityguide.rs. Ефекти појачавања видљивости и домета, спроведених на овај начин, биће истражени у наредном периоду. 
У овој групи напомена стоје и захтеви корисника за редовним ажурирањем сајта, постављањем актуелних информација на време и редовном објављивању препорука за читање и приказа приновљених књига. Седамнаесторо анкетираних $(4,67 \%)$ уочило је да је део информација и најава догађаја прекасно постављен, односно да изостају оне које су њима важне, попут препорука за читање и приказа нових наслова. Очекујемо да ће новоформирани онлајн каталог (OРAC) омогућити персонализовано корисничко искуство и отклонити велики део поменутог недостатка, јер ће омогућити да корисник креира сопствени налог и преко њега приступа својим подацима, као и да претражује и резервише жељене наслове. Део фонда у овом каталогу дат је у пуном тексту, слободан је за преузимање, а наслови су груписани тематски, визуелно лако прегледни и уочљиви, праћени додатним информацијама, приказима и слично.

Седморо анкетираних у приградским огранцима (1,92\%), тачније у Библиотечком огранку „Јован Јовановић Змај” у Футогу, тражило је посебне интернет странице за сваки библиотечки огранак, што је такође покривено интернет презентацијом Cityguide.rs, која промовише сваки огранак Библиотеке.

\section{Напомене у вези са техничким потешкоћама}

Укупно тридесет троје корисника $(\mathbf{9 , 0 7 \% )}$ предложило је побољшање на овом плану. Да постојећи електронски каталог не даје право стање и да се дешава да није у функцији приметило је осморо учесника у истраживању $(2,2 \%)$. На немогућност претраге по жанровима пажњу нам је скренуло њих тринаесторо (3,57\%). Могућност онлајн резервисања као предлог корисници су поменули и у оквиру другог питања у анкети, а као предлог за побољшање онлајн услуге дало га је њих дванаесторо $(3,3 \%)$. Све три тешкоће решавају се у оквиру новог Опака. Техничке потешкоће на интернет презентацијама Библиотеке у највећем броју уочили су корисници фондова градских одељења и огранака, њих дванаесторо (3,3\%), потом учесници у истраживању који су анкету попунили електронски, њих једанаесторо (3,02\%), а десеторо корисника фондова у приградским огранцима чини $2,75 \%$ анкетираних.

\section{Предлози за нове садржаје}

Од марта 2020, услед немогућности услуживања корисника у просторијама Библиотеке, YouTube канал Библиотеке, његова Фејсбук страница и сајт почели су убрзано да се попуњавају разноликим електронским 
садржајима. ${ }^{11}$ Нови Дигитални омладински центар отворио је страницу на Инстаграму. ${ }^{12}$

Резултати истраживања показали су да су корисници упознати са понудом онлајн услуга Библиотеке, те се укупно њих двадесет двоје $(\mathbf{6 , 0 4 \% )}$ својим предлозима надовезало на постојеће, сугеришући да се уведе: више видео-записа, блогова, квизова, такмичења и конкурса, стримовања занимљивих књижевних вечери, поучних видео-презентација, е-књиге и електронске интерактивне дебате за кориснике. Све наведено већ је део онлајн понуде Библиотеке, осим електронске књиге и интерактивне дебате за кориснике. Прва од њих за библиотеке још није регулисана у Републици Србији, па ћемо се тим питањем позабавити у наредном периоду. Интерактивну дебату могуће је имати, на пример, путем веб-сервиса Google Meet или Zoom и то користећи новоформирану Google групу. Занимљив нам је предлог да се у интернет понуду Библиотеке укључе и предлози за читање које дају корисници, што је део акционог плана библиотечке стратегије развоја, чему ће се свакако посветити пажња у наредном периоду.

Више видео-записа и блогова тражило је петоро анкетираних (1,37\%), по један из огранака $(0,27 \%)$ и троје који су попунили онлајн анкету $(0,83 \%)$; више квизова, такмичења и конкурса желело би двоје $(0,55 \%)$, један корисник фондова градских одељења и огранака $(0,27 \%)$ и један испитаник путем интернета (0,27\%); стримовање занимљивих књижевних вечери предложило је осморо (2,2\%), од чега петоро (1,37\%) електронски, један у градским $(0,27 \%)$ и двоје $(0,55 \%)$ у приградским огранцима; више поучних видео-презентација и е-књиге тражило је троје $(0,83 \%)$, по један $(0,27 \%)$ из сваке области анкете; четворо је тражило електронске интерактивне дебате за кориснике $(1,1 \%)$, и то један анкетирани у граду $(0,27 \%)$ и троје путем електронске анкете $(0,83 \%)$. Највише иновација у садржинском смислу тражили су учесници у истраживању који су анкету попунили електронски, њих тринаесторо (3,57\%), петоро их је било из градских $(1,37 \%)$ и четворо из приградских огранака (1,1\%).

Једанаесторо њих $(\mathbf{3 , 0 2} \%)$ изјаснило се да не зна како побољшати електронске услуге Библиотеке, од чега већина анкетираних у приградским огранцима - њих деветоро (2,47\%) - и двоје у градским (0,55\%). Одговор да не зна није дао ниједан учесник у електронској анкети.

11 В. поменути рад Весне Живковић и рубрику Диіитиално чийаюе у гласилу „Мозаик” год. XXII, бp. 133 (2020).

12 https://www.instagram.com/gbns.doc/. 


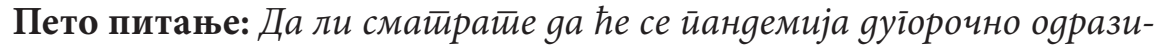

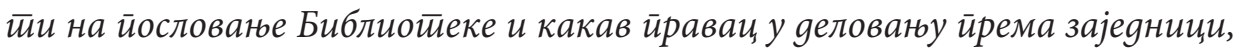

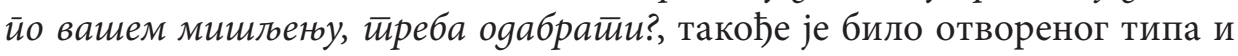
добијени су следећи одговори:

а) (Без одговора).

б) Одразиће се на лош начин због немогућности приступа фонду и личног контакта са књигом.

в) Одразиће се на лош начин јер су млади на интернету. Треба дигитализовати што више материјала и организовати онлајн програме.

г) Мање ће се читати, али ће библиотека опстати. 16

д) Неће се одразити - ко хоће да чита - тај чита. 173

ђ) Више ће се читати. 26

е) Више ће се користити е-књиге и кућна достава. 11

(Више маркетинга, више онлајн промоција, више програма на отвореном). 3

ж) Одразиће се јер се одразила на све (без назнаке како). 50

з) Не знам. 16

Сви одговори могу се груписати у три сценарија, како се види у Табели 6.

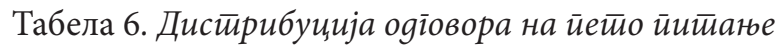

\begin{tabular}{|c|l|c|c|c|}
\hline & $\begin{array}{c}\text { Оптимистички } \\
\text { сценарио }\end{array}$ & $\begin{array}{c}\text { Песимистички } \\
\text { сценарио }\end{array}$ & $\begin{array}{c}\text { Неутрални } \\
\text { сценарио }\end{array}$ \\
\hline 1. & $\begin{array}{l}\text { Градска одељења } \\
\text { и огранци }\end{array}$ & $\begin{array}{c}\mathbf{6 0} \\
(16,48 \%)\end{array}$ & $\begin{array}{c}\mathbf{2 1} \\
(5,77 \%)\end{array}$ & $\begin{array}{c}\mathbf{3 9} \\
(10,71 \%)\end{array}$ \\
\hline 2. & $\begin{array}{l}\text { Приградски } \\
\text { огранци }\end{array}$ & $\begin{array}{c}\mathbf{1 0 3} \\
(28,30 \%)\end{array}$ & $\begin{array}{c}\mathbf{1 3} \\
(3,57 \%)\end{array}$ & $\begin{array}{c}\mathbf{4 8} \\
(13,18 \%)\end{array}$ \\
\hline 3. & $\begin{array}{l}\text { Електронска } \\
\text { анкета }\end{array}$ & $\mathbf{5 0}$ & $\mathbf{1 6}$ & $\mathbf{1 4}$ \\
\hline & Укупно & $\mathbf{2 1 3}$ & $(4,40 \%)$ & $(3,85 \%)$ \\
\hline
\end{tabular}

Оптимистички сценарио обухвата неколико начина размишљања корисника: једно је да пандемија неће утицати на улогу библиотека у друштву, како сматрају 173 корисника (47,52\%); друго каже да ће библиотека у овим ванредним околностима постати још видљивија и потребнија, како мисли двадесет шесторо (7,14\%), а треће предвиђа да ће ситуација допринети још 
бољем пословању библиотеке и то развијањем важних грана пословања: руковања електронском књигом и развијања сервиса доставе (11 анкетираних, или 3,02\%). У ову групу се убраја и подгрупа предлога која се појавила само у оквиру одговора у електронској анкети, а то је развојна могућност коју су уочили корисници: више маркетинга, више онлајн промоција и више програма на отвореном (троје, односно 0,82\%). Укупан број од 213 $(\mathbf{5 8}, \mathbf{5 2} \%)$ анкетираних пред Библиотеком виде светлу будућност. Највећи број оптимиста налазимо у приградским огранцима, 103 (28,30\%).

Песимистички сценарио предвиђа да ће се пандемија лоше одразити на пословање библиотеке због немогућности приступа фонду и личног контакта са књигом - овај став заступа 18 учесника у истраживању (4,95\%). Шеснаесторо $(4,4 \%)$ има оних који сматрају да библиотеку у доба пандемије угрожава чињеница да су млади претежно на интернету и не читају, тако да треба дигитализовати што више материјала и организовати онлајн програме. Исти број анкетираних сматра да ће се мање читати, али да ће библиотека опстати $(4,4 \%)$. Број анкетираних који заступају песимистички сценарио је 50, што чини 13,74\% од укупног броја.

Неутрални сценарио заступају они који нису одговорили на ово питање, њих 35 (9,62\%), педесеторо који сматрају да ће се епидемија одразити на пословање Библиотеке, али не кажу на који начин $(13,73 \%)$ и шеснаесторо $(4,39 \%)$ који су се изјаснили да не знају. Укупан број заступника неутралног, тј. неопредељеног става, јесте 101, или $27,74 \%$.

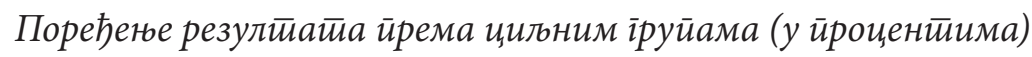

\section{Прво питање:}

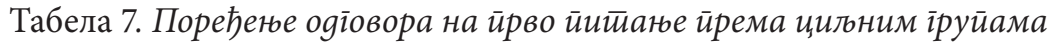

\begin{tabular}{|c|l|c|c|c|c|}
\cline { 3 - 5 } \multicolumn{2}{c|}{} & $\begin{array}{c}\text { Веома } \\
\text { добре }\end{array}$ & Добре & $\begin{array}{c}\text { Задовоља- } \\
\text { вајуће }\end{array}$ & Лоше \\
\hline 2. & $\begin{array}{l}\text { Градска одељења } \\
\text { и огранци }\end{array}$ & 68,33 & 25,83 & 5,00 & 0,83 \\
\hline 3. & Приградски огранци & 64,63 & 20,12 & 14,63 & 0,61 \\
\hline & Електронска анкета & 67,50 & 22,50 & 10,00 & 0,00 \\
\hline
\end{tabular}




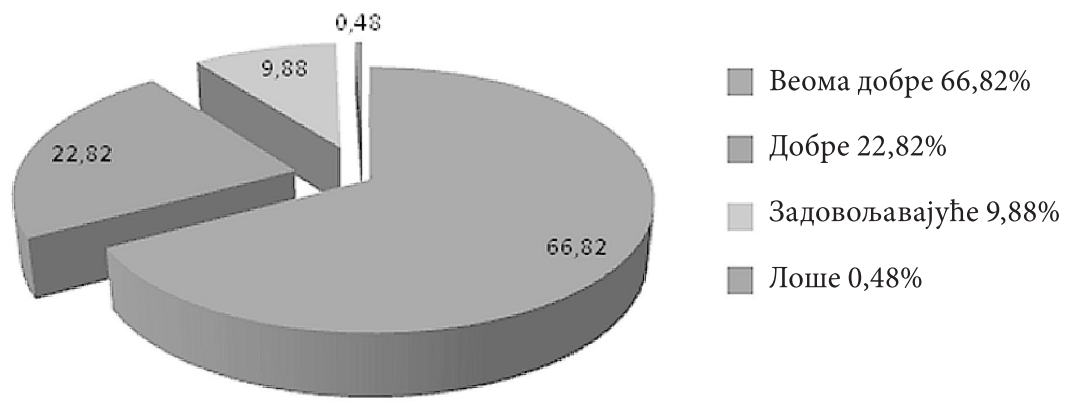

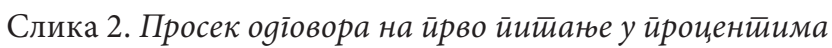

Друго питање:

Табела 8. Поређенье оgі̄овора на gруі̄о ӣитиане йрема иильним іруйама

\begin{tabular}{|c|c|c|c|c|c|c|c|c|}
\hline & & 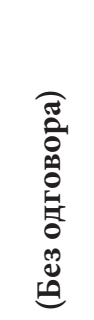 & 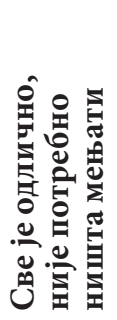 & 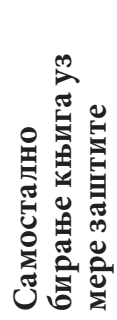 & 畄 & 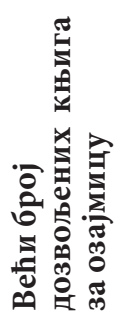 & 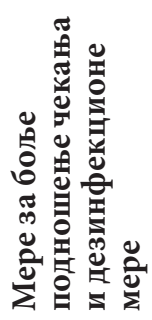 & 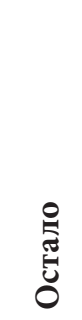 \\
\hline 1. & $\begin{array}{l}\text { Градска } \\
\text { одељења } \\
\text { и огранци }\end{array}$ & 29,16 & 30,00 & 10,00 & 12,50 & 9,17 & 9,17 & 0,00 \\
\hline 2. & $\begin{array}{l}\text { Приградски } \\
\text { огранци }\end{array}$ & 14,63 & 37,80 & 9,77 & 0,00 & 1,83 & 21,34 & 14,63 \\
\hline \multirow[t]{2}{*}{3.} & $\begin{array}{l}\text { Електронска } \\
\text { анкета }\end{array}$ & 3,75 & 66,25 & 6,25 & 2,50 & 0,00 & 21,25 & 0,00 \\
\hline & Просек & 15,85 & 44,68 & 8,67 & 5,00 & 3,67 & 17,25 & 4,88 \\
\hline
\end{tabular}




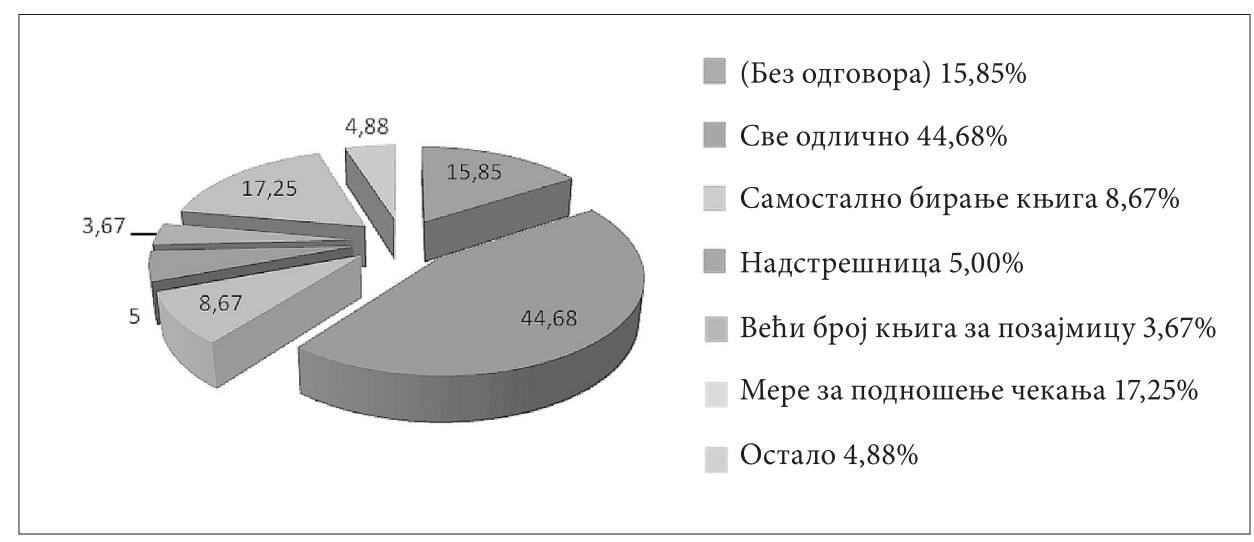

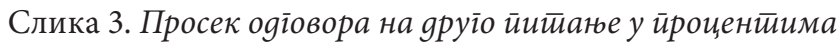

\section{Tреће питање:}

Табела 9. Поређене оgі̄овора на ӣреће йийане йрема ициьним ірруйама

\begin{tabular}{|c|l|c|c|c|c|}
\cline { 2 - 5 } \multicolumn{2}{l|}{} & Често & Понекад & Ретко & Никад \\
\hline 2. & Прадска одељења & 10,00 & 33,33 & 25,83 & 30,84 \\
\hline 3. & Приградски огранци & 11,59 & 31,10 & 31,71 & 25,60 \\
\hline & Плектронска анкета & 22,50 & 36,25 & 23,75 & 17,50 \\
\hline
\end{tabular}
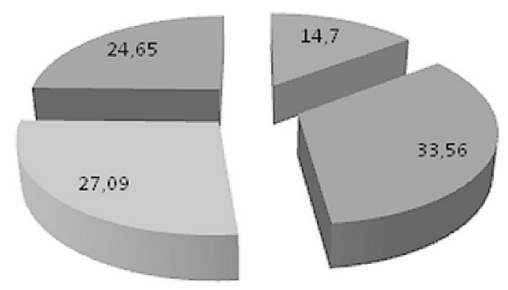

Често $14,70 \%$

Понекад 33,56\%

Ретко 27,09\%

Никад $24,65 \%$ 


\section{Четврто питање:}

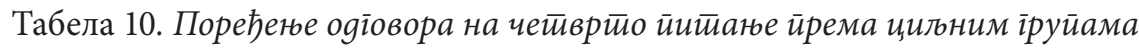

\begin{tabular}{|c|c|c|c|c|c|c|c|}
\hline & & 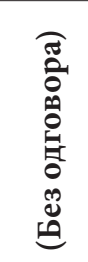 & 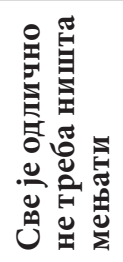 & 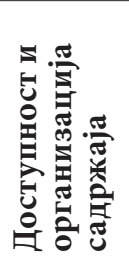 & 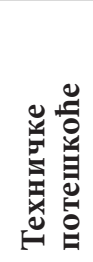 & 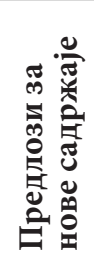 & 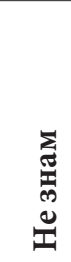 \\
\hline 1. & $\begin{array}{l}\text { Градска одељења } \\
\text { и огранци }\end{array}$ & 70,00 & 7,50 & 6,67 & 10,00 & 4,17 & 1,67 \\
\hline 2. & $\begin{array}{l}\text { Приградски } \\
\text { огранци }\end{array}$ & 53,05 & 21,34 & 11,59 & 6,10 & 2,43 & 5,49 \\
\hline \multirow[t]{2}{*}{3.} & $\begin{array}{l}\text { Електронска } \\
\text { анкета }\end{array}$ & 18,75 & 45,00 & 6,25 & 13,75 & 16,25 & 0,00 \\
\hline & Просек & 47,27 & 24,61 & 8,17 & 9,95 & 7,62 & 2,38 \\
\hline
\end{tabular}
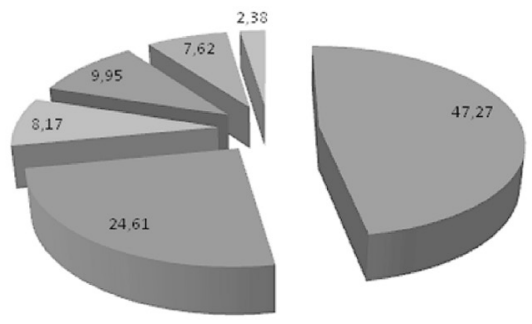

Без одговора $47,27 \%$

Све је одлично $24,61 \%$

Доступност и орг. садржаја $8,17 \%$

Техничке потешкоће $9,95 \%$

Предлози за нове садржаје 7,62\%

Не знам $2,38 \%$

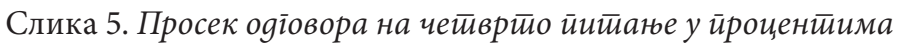

\section{Пето питање:}

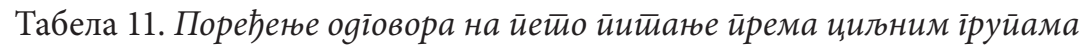

\begin{tabular}{|c|l|c|c|c|}
\cline { 3 - 5 } \multicolumn{2}{c|}{} & $\begin{array}{c}\text { Оптимистички } \\
\text { сценарио }\end{array}$ & $\begin{array}{c}\text { Песимистички } \\
\text { сценарио }\end{array}$ & $\begin{array}{c}\text { Неутрални } \\
\text { сценарио }\end{array}$ \\
\hline 1. & $\begin{array}{l}\text { Градска одељења } \\
\text { и огранци }\end{array}$ & 50,00 & 17,50 & 32,50 \\
\hline 2. & $\begin{array}{l}\text { Приградски } \\
\text { огранци }\end{array}$ & 62,80 & 7,93 & 29,27 \\
\hline 3. & Електронска анкета & 62,50 & 20,00 & 17,50 \\
\hline & Просек & $\mathbf{5 8 , 4 3}$ & $\mathbf{1 5 , 1 4}$ & $\mathbf{2 6 , 4 2}$ \\
\hline
\end{tabular}




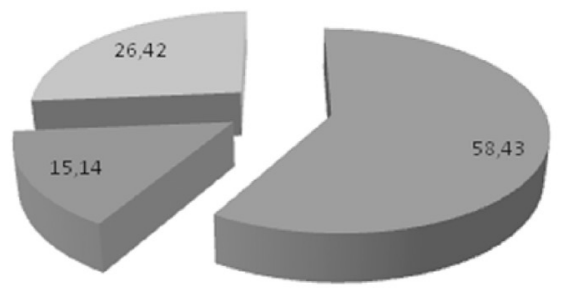

Оптимистички сценарио $58,43 \%$

Песимистички сценарио $14,14 \%$

Неутрални сценарио $26,42 \%$

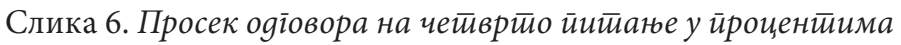

\section{Закључак}

Од 6. августа до 18. септембра 2020, у 22 одељења и огранка Градске библиотеке у Новом Саду, као и путем њеног сајта и платформе Google Forms, прикупљена су укупно 364 попуњена упитника. Већина одговора на анкету стигла су из библиотечке мреже, од корисника који су физички посетили библиотеку. Највећи број одговора дали су корисници фондова у приградским огранцима.

Просек у одговорима на прво питање показује да већина анкетираних сматра да су мере заштите уведене у библиотечку мрежу веома добре и добре, што представља огромну већину посетилаца који одлазак у Библиотеку не сматрају ризичним по своје здравље и задовољни су пруженом услугом. Најзадовољнији су корисници градских одељења и огранака, а највише примедби имају корисници приградских огранака.

На друго питање, које је тражило конкретне одговоре на то шта је по питању позајмице потребно мењати, више од половине корисника било је без примедби. Остали корисници могу се сврстати у две веће групе: једну чине они који траже побољшање мера за боље подношење чекања и друга група тражи да им се одобри улазак у библиотеку како би самостално бирали књиге. Као алтернативу овоме предложили су да им се омогући коришћење таблета или ноутбука да би могли електронски да претражују фонд на улазу у Библиотеку.

Најзадовољнији су корисници анкетирани електронским путем. Надстрешницу и већи број књига за позајмицу желе првенствено корисници градских одељења и огранака. Када је у питању позајмица, треба рећи још 
да се у време када су резултати истраживања били у обради, на пултове у одељењима и огранцима у граду и приградским насељима започело постављање заштитног плексигласа.

На треће питање у упитнику корисници су се изјашњавали бирајући један од понуђених одговора у вези са тим да ли електронске презентације Библиотеке на интернету посећују често, понекад, ретко или никад. Велики број суграђана зна за Библиотеку на интернету, али је број оних који редовно користе ову интернет услугу сразмерно мали. Зато смо се потрудили да пронађемо начин да онлајн услугу учинимо видљивијом и приступачнијом, а постојеће и нове онлајн услуге детаљније су представљене у четвртом питању.

У одговорима на четврто питање просек броја учесника без примедби близу је половини, а оне које су на овом плану корисници изнели можемо сврстати у три групе. У просеку највећи број корисника жалио се на техничке потешкоће, затим на доступност и организацију садржаја, а део их је износио предлоге за нове садржаје. Најзадовољнији су корисници који су попуњавали анкету у електронском облику, а и највећи број их је, у односу на кориснике огранака и одељења, дао предлоге за нове садржаје.

Постојећи асортиман услуга које су корисници могли да користе путем YouTube канала, Фејсбук странице и сајта Библиотеке обогаћен је новим садржајима који су почели убрзано да се развијају у марту 2020, након увођења ванредног стања, а који нису престали да се развијају и богате ни данас. У јулу је отворена страница на Инстаграму, а у септембру оформљена корисничка Google група која броји преко 1.500 чланова, чиме су се информисаност и интеракција са корисницима додатно побољшале. Ова група биће полазна основа за креирање мобилне апликације. Развијање електронског облика пословања један је од циљева из Сӣратиеіије развоја Граяске библиотеке у Новом Саgу, донете у септембру 2019, који је у условима пандемије додатно добио на значају и чији су задаци почели убрзано да се реализују.

Нова услуга коју Библиотека однедавно нуди јесте Опак (Орас), онлајн каталог за персонализовану употребу корисника, а у завршној фази је и нови сајт Библиотеке, израђен по најсавременијим стандардима. Дигитални омладински центар, који је отворен у јуну 2020, производи онлајн садржаје занимљиве пре свега младима, али и свим другим старосним категоријама, преносећи уживо и снимајући концерте, промоције књига, разговоре, фестивале, радионице и друго. Осим тога, радиће се и на увођењу позајмице електронске књиге, где је први корак постављање сопствених издања у пуном тексту у онлајн каталог. Нова интернет презентација сваког 
одељења и огранка Библиотеке понаособ, на сајту Cityguide.rs, такође ће обезбедити већу видљивост Библиотеке на интернету.

Утицај развоја електронских услуга доступних путем интернета биће предмет посебних истраживања у долазећем периоду.

Пето питање тицало се будућности Библиотеке, а одговори корисника могу се сврстати у три сценарија. Оптимистички сценарио заступа највећи број анкетираних који кажу да пандемија неће утицати на улогу библиотека у друштву, да ће библиотека у овим ванредним околностима постати још видљивија и потребнија и да ће епидемија допринети још бољем пословању библиотеке и то развијањем важних грана пословања: руковања електронском књигом и развијања сервиса доставе. Подједнак број оптимиста налазимо у приградским огранцима и међу корисницима који су анкету попунили путем интернета.

Песимистички сценарио предвиђа да ће се пандемија лоше одразити на пословање библиотеке и то пре свега због немогућности приступа фонду и личног контакта са књигом, као и чињенице да су млади претежно на интернету и не читају, тако да треба дигитализовати што више материјала и организовати онлајн програме. Један број анкетираних сматра да ће се свакако мање читати, али да ће Библиотека опстати.

Неутрални сценарио заступају они који нису одговорили на ово питање, затим они који сматрају да ће се епидемија одразити на пословање Библиотеке, али не кажу на који начин, и они који су се изјаснили да не знају.

Резултати анкете потврдили су почетну тезу - да су корисници у већем броју задовољни начином на који Библиотека ради, да су им интернет садржаји и услуге доступни и интересантни и да у будућности не виде веће промене у библиотечком пословању. Сугестије које су нам учесници истраживања упутили корисне су као путоказ за развијање нових услуга,

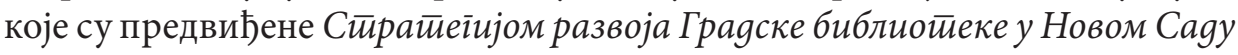
(2020-2024), ${ }^{13}$ у оквиру Стратешког циља 2 - Увођене иноващија и раg на

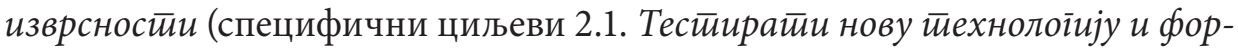

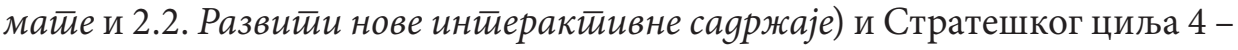
Развој йублике (специфични циљеви 4.1. Креиратии саgржаје за ирривлачене

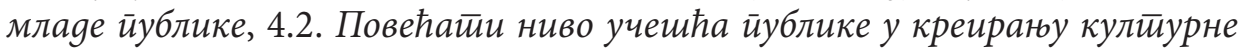

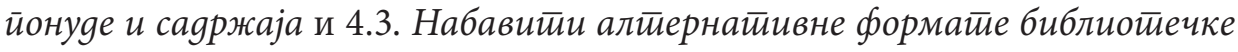
ірађе раgи ирривлачења нове йублике). Пандемија корона вируса додатно је убрзала реализацију ових циљева.

13 Градска библиотека у Новом Саду, Сӣрайеїија развоја Граgске библиоиееке у Новом Саgу (2020-2024), 10, 12. 


\section{Literatura:}

1. Gradska biblioteka u Novom Sadu. Plan primene mera zaštite zaposlenih u Gradskoj biblioteci u Novom Sadu za vreme trajanja vanrednog stanja. Novi Sad: S. Miljuš, 2020, https://www.facebook.com/GradskaBibliotekaNoviSad/photos /a.367124053302423/3623961180952011 (preuzeto 24. 4. 2020).

2. Gradska biblioteka u Novom Sadu. Strategija razvoja Gradske biblioteke u Novom Sadu (2020-2024). Novi Sad: A. Jokanović i B. Grujić, 2019. (na ćirilici).

3. Gradska biblioteka u Novom Sadu. Strategija razvoja Gradske biblioteke u Novom Sadu (2020-2024). Novi Sad: A. Jokanović i B. Grujić, 2019, https://www.gbns. rs/images/dokumenti/STRATEGIJA_RAZVOJA_2020-2024.pdf (preuzeto 3. 10. 2020). (na ćirilici); Novi Sad City Library, Strategic Plan 2020-2024. Novi Sad: A. Jokanović i B. Grujić, 2019, https://www.gbns.rs/images/dokumenti/STRATEGIC_PLAN_2020-2024.pdf (preuzeto 3. 10. 2020).

4. Instagram. https://www.instagram.com/gbns.doc/ (preuzeto 3. 10. 2020).

5. Mozaik. Digitalno čitanje. Gradska biblioteka u Novom Sadu god. XXII, br. 133 (2020), u pripremi (na ćirilici).

6. Živković, Vesna. „Kulturni programi tokom pandemije kovida-19”. Bibliotekar god. LXII, sv. 2 (2020), rad prihvaćen za štampanje (na ćirilici). 


\author{
Bojana Č. Grujić \\ Novi Sad City Library, Novi Sad \\ bojana.grujic3@gmail.com
}

\title{
THE WORK OF NOVI SAD CITY LIBRARY DURING THE COVID-19 PANDEMIC - AUDIENCE RESEARCH
}

\begin{abstract}
After the outbreak of the infectious disease covid 19, caused by the corona virus, Novi Sad City Library adjusted its work to the epidemiological situation and adopted a Plan for the Implementation of Measures for the Protection of Employees in Novi Sad City Library During the State of Emergency. In the first year of implementation of the Library's Strategic Plan 2020-2024, the initial research of the audience is planned, as well as the fulfillment of the strategic goals of introducing innovations and developing the audience. Accordingly, in August-September 2020, a users survey was conducted, in order to gain insight into attitudes towards the way the Library operates and how to improve the user experience. In addition to accepting the measures taken within the book-loan service and suggestions for its improvement, the focus of the research was the attitude towards online library services and user predictions of the future for the library as an institution. The attitudes of the users in city departments and branches were compared with the views of the users in suburban branches and those who filled in the survey in electronic form. A wide range of online services began to develop even before the pandemic, as strategically predicted, and the expansion of the contagion has further accelerated efforts in this field.
\end{abstract}

Keywords: Novi Sad City Library, pandemic, covid-19, corona virus, audience research, user experience, survey, services.

Примљено: 5. октобра 2020.

Исправке: 6. новембра 2020.

Прихваћено: 11. новембра 2020. 